\title{
Nonlinear Static Pushover Analysis of Medium Rise and High-Rise Building
}

\author{
Dr. M Keshava Murthy ${ }^{1}$, Ashwini L K ${ }^{2}$
}

${ }^{1}$ Professor, Department of Civil Engineering, University Visvesvaraya College of Engineering, Bengaluru, Karnataka, India

${ }^{1}$ Research Scholar Department of Civil Engineering, University Visvesvaraya College of Engineering, Bengaluru, Karnataka, India

\begin{abstract}
Pushover analysis is an elegant tool to visualise the performance level of a building under a given earthquake. The purpose of the paper is to summarize the Non Linear static Pushover analysis of medium rise RC bare frame and high rise RC infilled structure with soft stories at different levels using ETABS software. Results concluded that due to the introduction of soft stories in the higher level the intensity of hinge formation becomes lower and lower and at the same time displacement and base shear increases
\end{abstract}

Keywords : Pushover Analysis, Hinges, Base Shear,, Displacement

\section{INTRODUCTION}

Seismic design can be viewed as a two step process. The first and usually most important one, is the conception of an effective structural system that needs to be configured with due regard to all the important seismic performance objectives, ranging from serviceability considerations to life safety and collapse prevention. This step comprises the art of seismic engineering, since no rigid rules can,or should, be imposed on the engineer's creativity to devise a system that not only fulfils seismic performance objectives, but also pays tribute to functional and economic constraints imposed by owner, the architect and other professionals involved in the design and construction of a building. By default, this process of creation is based on judgement, experience and understanding of seismic behaviour, rather than rigorous mathematical formulation. Rules of thumb for strength and stiffness targets, based on the fundamental knowledge of ground motion and elastic and inelastic dynamic response characteristics, should suffice to configure and rough size an effective structural system.

Elaborate mathematical/physical models can only be built once a structural system has been created. Such modles are needed to evaluate seismic performance of an existing system and to modify component behaviour characteristics ( strength, stiffness, deformation capacity) to better suit the specified performance criteria. This second step of the design process should involve a demand/capacity evaluation at all the important performance levels, which requires identification of important capacity parameters and prescription of acceptable values of these parameters, as well as the prediction of the demands imposed by ground motions.

\section{METHODS AND MATERIAL}

\section{A. Purpose of the pushover analysis}

The purpose of the pushover analysis is to evaluate the expected performance of a structural system by estimating its strength and deformation demands in 
design earthquakes by means of a static inelastic analysis and comparing these demands to available capacities at the performance levels of interest. The evaluation is based on the assessment of important performance parameters, including global drift, interstorey drift, inelastic element deformations (either absolute or normalised with respect ta a yield value), deformations between elements and element and connection forces(for elements and connections that cannot sustain inelastic deformation).

The inelastic static pushover analysis can be viewed as a method for predicting seismic force and deformation methods, which accounts in an approximate manner for the redistribution of internal forces occurring when the structure is subjected to inertia forces that no longer can be resisted within the elastic range of structural behaviourThe push over is expected to provide information on many response characteristics that cannot be obtained from an elastic static or dynamic analysis

The following steps stated below.

- Identification of location of weak points in the structure( or potential failure modes)

- Identification of the critical regions in which the deformation demands are expected to be high and that have to become the focus through detailing.

- Determination of force demands on brittle members, such as axial force demands on columns, moment demands on beam-column connections.

- The realistic force demands on potentially brittle elements, such as axial force demands on columns, force demands on brace connection, moment demands on beam to column connections, shear force demands in deep reinforced concrete spandrel beams, shear force demands in unreinforced masonry wall peirs, etc.

- Estimates of the deformations demands for elements that have to form in elastically in order to dissipate the energy imparted to the structures.

Verification of the completeness and adequacy of load path, considering all the elements of the structural system, all the connections, the stiff nonstructural elements of significant strength, and the foundation system

\section{B. Pushover analysis background}

Non linear static pushover analysis has become the most commonly used method to determine the nonlinear behaviour of the building structures in the recent years. In this simplified method, a capacity curve is obtained which shows the relation of base shear and roof displacement. This curve represents the behaviour of the building structure under increasing base shear forces. As the capacities of the members of the lateral force resisting system exceed their yield limits during the increasing of the base shear force, the slope of the force deformation curve will change, and hence the nonlinear behaviour can be represented. In the pushover analysis, the applied lateral forces to a model are increased in a regular manner depending on the initial load pattern. Member forces are calculated for each step andt he stiffness of the members whose capacities are exceeded is changed according to the hinge properties in the next step of analysis. The pushover analysis can be performed considering the control over the force or displacement. Force control option is useful when the magnitude of the load is known clearly, and the structure is expected to support that load. 
The displacement control is useful when the magnitude of the load is unknown and displacements are searched. The recent advent of performance based design has brought the nonlinear static pushover analysis procedure to the forefront. Pushover analysis is a static, nonlinear procedure in which the magnitude of the structural loading is incrementally increased in accordance with a certain predefined pattern. With the increase in the magnitude of the loading, weak links and failure modes of the structure are found. The loading is monotonic with the effects of the cyclic behaviour and load reversals being estimated by using a modified monotonic force deformation criteria and with damping approximations

\section{Modelling and analysis}

The general finite element package ETABS has been used for the modelling and analysis. It is a versatile and user-friendly program that offers a wide scope of features like static and dynamic analysis, nonlinear dynamic analysis and nonlinear static pushover analysis, etc. These features and many more, make ETABS the state-of-the-art in structural analysis programs.

Nonlinear static pushover analysis is a very powerful feature offered in the nonlinear version of ETABS Pushover analysis can be performed on both two and three dimensional structural models. In ETABS pushover analysis can consist of any number of pushover cases and each pushover case can have a different distribution of lateral load on the structure. A pushover case may start from zero initial conditions, or it may start from the end of a previous pushover case. ETABS can also perform pushover analysis as either force-controlled or displacementcontrolled.

\section{RESULTS AND DISCUSSION}

NUMERICAL STUDY 1. Push Over Analysis of Medium Rise RC building

A 5 storey building has been analyzed using Nonlinear static pushover analysis method. The building consists of 5bays along length and width. The end bays are $5.5 \mathrm{~m}$, intermediate bays are $5 \mathrm{~m}$ and central bay is $3 \mathrm{~m}$ along both the direction. The size of the beam is $500 \mathrm{mmX} 300 \mathrm{~mm}$ and size of the column is $450 \mathrm{mmX} 300 \mathrm{~mm}$. the building

Table 1.1 Building description

\begin{tabular}{|l|l|l|}
\hline Sl no & \multicolumn{1}{|c|}{ Title } & \multicolumn{1}{|c|}{ Description } \\
\hline 1 & No of storey & 5 \\
\hline 2 & Size of Beam & $500 \mathrm{mmx} 300 \mathrm{~mm}$ \\
\hline 3 & Size of Column & $450 \mathrm{mmx300mm}$ \\
\hline 4 & Earthquake Zone & II \\
\hline 5 & Soil type & Medium \\
\hline 6 & Importance factor & 1 \\
\hline 7 & Zone factor & 0.16 \\
\hline 8 & Storey height & $3 \mathrm{~m}$ \\
\hline 9 & $\begin{array}{l}\text { Grade of Steel and } \\
\text { Concrete }\end{array}$ & Fe415 and M30 \\
\hline
\end{tabular}

Plan of the five storey building

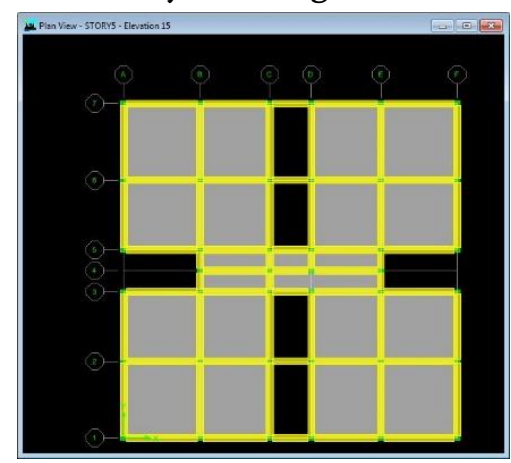

Fig 1.1(a) pushover curve for five storey building 


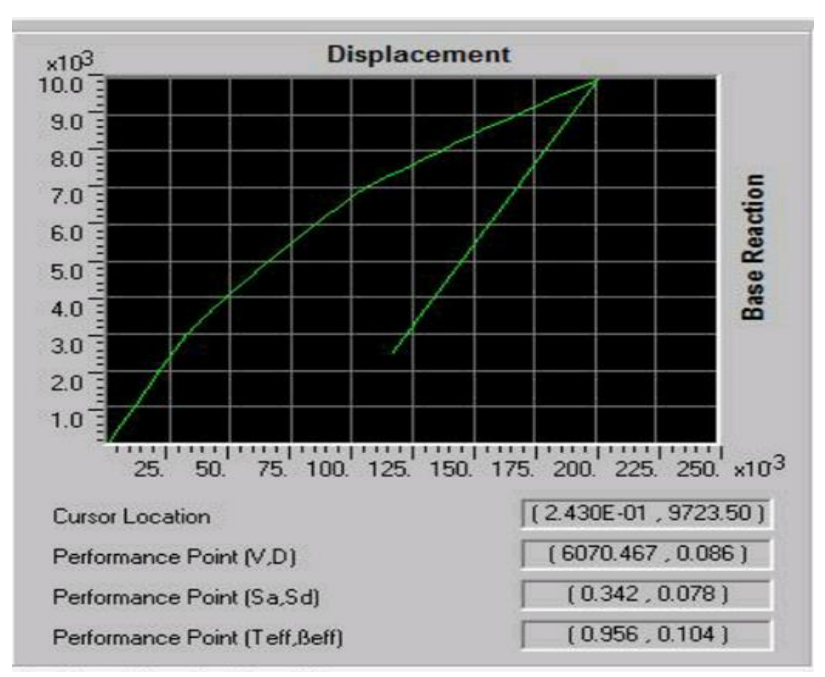

Fig 1.1(b) capacity demand spectrum for five storey building

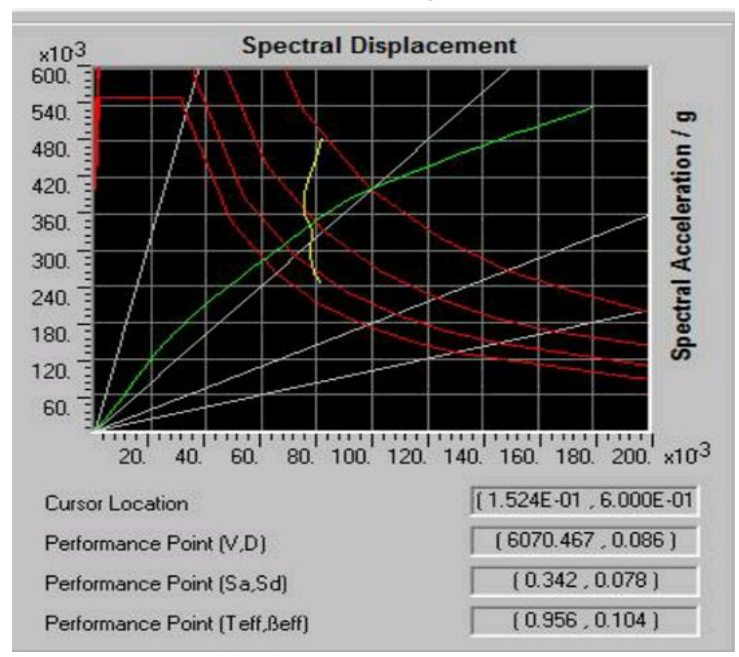

Fig 1.1(c) hinge levels for five storey building

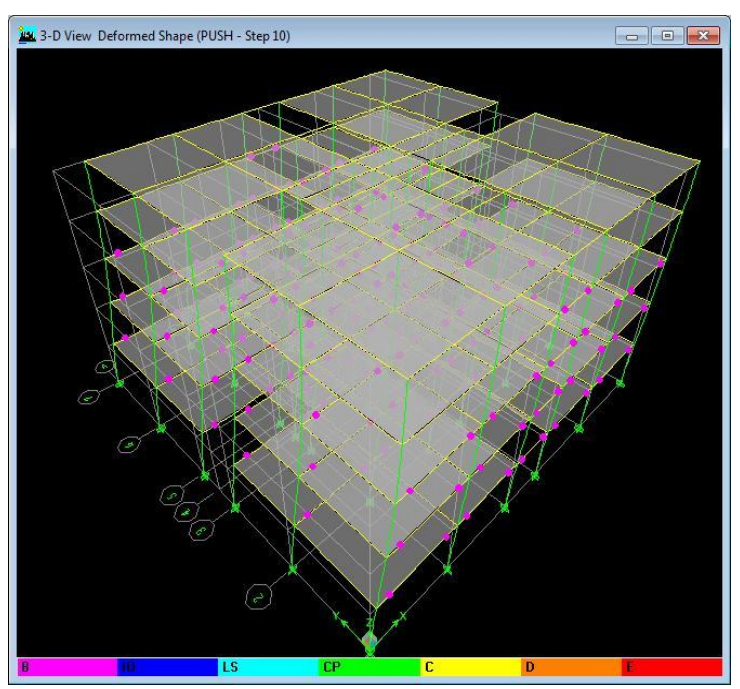

Table 1.2 : Stepwise displacement and base force for five storey building

\begin{tabular}{|c|c|c|}
\hline Step & Displacement & Base Force \\
\hline 0 & 0 & 0 \\
\hline 1 & 0.0052 & 494.9527 \\
\hline 2 & 0.0104 & 989.9053 \\
\hline 3 & 0.0156 & 1484.858 \\
\hline 4 & 0.0208 & 1979.811 \\
\hline 5 & 0.0217 & 2069.908 \\
\hline 6 & 0.0271 & 2554.388 \\
\hline 7 & 0.0328 & 3017.408 \\
\hline 8 & 0.039 & 3442.906 \\
\hline 9 & 0.0454 & 3829.466 \\
\hline 10 & 0.0516 & 4196.145 \\
\hline 11 & 0.0575 & 4530.473 \\
\hline 12 & 0.0629 & 4822.346 \\
\hline 13 & 0.0688 & 5144.571 \\
\hline 14 & 0.0771 & 5595.889 \\
\hline 15 & 0.0829 & 5906.718 \\
\hline 16 & 0.0893 & 6241.359 \\
\hline 17 & 0.095 & 6520.306 \\
\hline 18 & 0.1017 & 6817.089 \\
\hline 19 & 0.1087 & 7088.877 \\
\hline 20 & 0.1139 & 7262.456 \\
\hline 21 & 0.1191 & 7436.035 \\
\hline 22 & 0.1243 & 7609.614 \\
\hline 23 & 0.1295 & 7783.193 \\
\hline 24 & 0.1368 & 8029.041 \\
\hline 25 & 0.142 & 8202.586 \\
\hline 26 & 0.1482 & 8406.963 \\
\hline 27 & 0.1541 & 8597.975 \\
\hline 28 & 0.1615 & 8822.205 \\
\hline 29 & 0.1702 & 9075.472 \\
\hline 30 & 0.1758 & 9236.729 \\
\hline 31 & 0.181 & 9385.303 \\
\hline 32 & 0.1873 & 9564.24 \\
\hline 33 & 0.1947 & 9777.944 \\
\hline 34 & 0.1999 & 9923.796 \\
\hline 35 & 0.2013 & 9959.591 \\
\hline 36 & 0.116 & 2451.538 \\
\hline
\end{tabular}


Numerical study 2 : Push Over Analysis of Tall Buildings with Soft Stories at Different Levels

A 22 storey building has been analysed using non linear static pushover analysis method. The building consists of 22 storeys with soft storey at different levels in addition to one at ground floor using ETABS. The objective of this study is to see the variation of load displacement graph and to check the maximum base shear and displacement of the frame with soft stories at different levels.

Table 2.1 Building Description

\begin{tabular}{|c|c|c|}
\hline Sl no & Title & Description \\
\hline 1 & No of storey & 20 \\
\hline 2 & Size of Beam & $300 \mathrm{~mm} \times 500 \mathrm{~mm}$ \\
\hline 3 & Size of Column & $\begin{array}{l}300 \mathrm{~mm} \times 600 \mathrm{~mm} \text { and } \\
300 \mathrm{mmx} 1200 \mathrm{~mm}\end{array}$ \\
\hline 4 & $\begin{array}{l}\text { Earthquake } \\
\text { Zone }\end{array}$ & V \\
\hline 5 & Soil type & Medium \\
\hline 6 & $\begin{array}{l}\text { Importance } \\
\text { factor }\end{array}$ & 1 \\
\hline 7 & Zone factor & 0.36 \\
\hline 8 & Storey height & $3 \mathrm{~m}$ \\
\hline 9 & $\begin{array}{l}\text { Grade of Steel } \\
\text { and Concrete }\end{array}$ & Fe415 and M20 \\
\hline 10 & $\begin{array}{l}\text { Weight density } \\
\text { of brick } \\
\text { Masonry }\end{array}$ & $20 \mathrm{KN} / \mathrm{m} 3$ \\
\hline 11 & $\begin{array}{l}\text { Weight Density } \\
\text { of RC material }\end{array}$ & $25 \mathrm{KN} / \mathrm{m} 3$ \\
\hline 12 & Thickness of slab & $150 \mathrm{~mm}$ \\
\hline
\end{tabular}

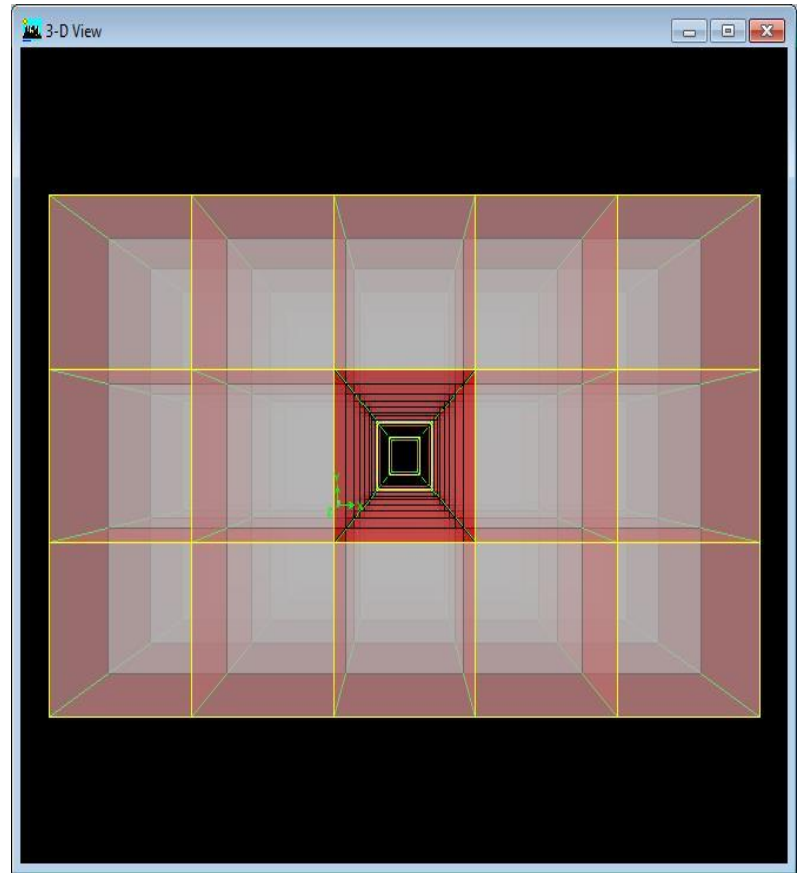

Plan of the 22 storey building

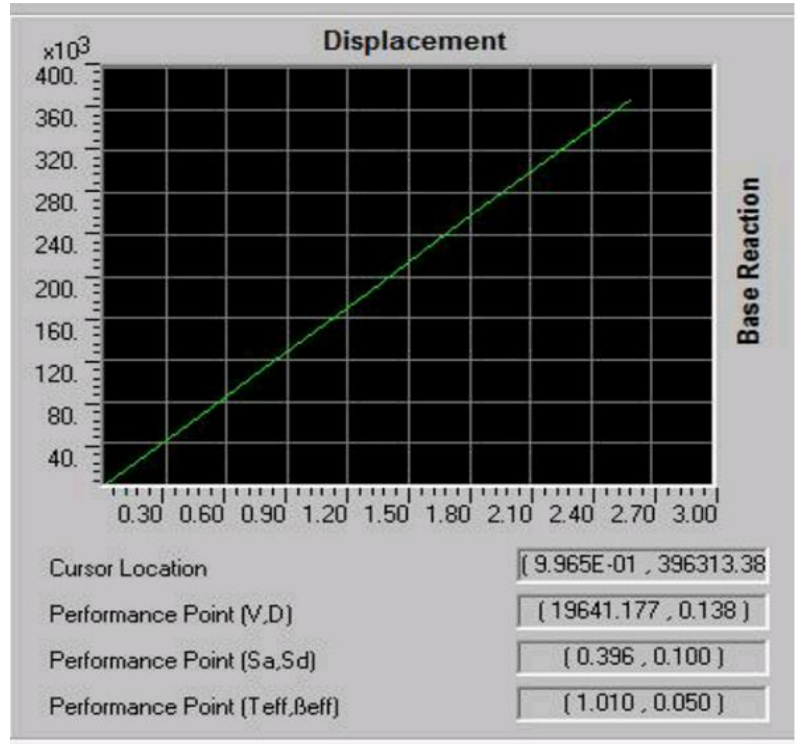

Fig 2.1(a) pushover curve for 22 storey building 


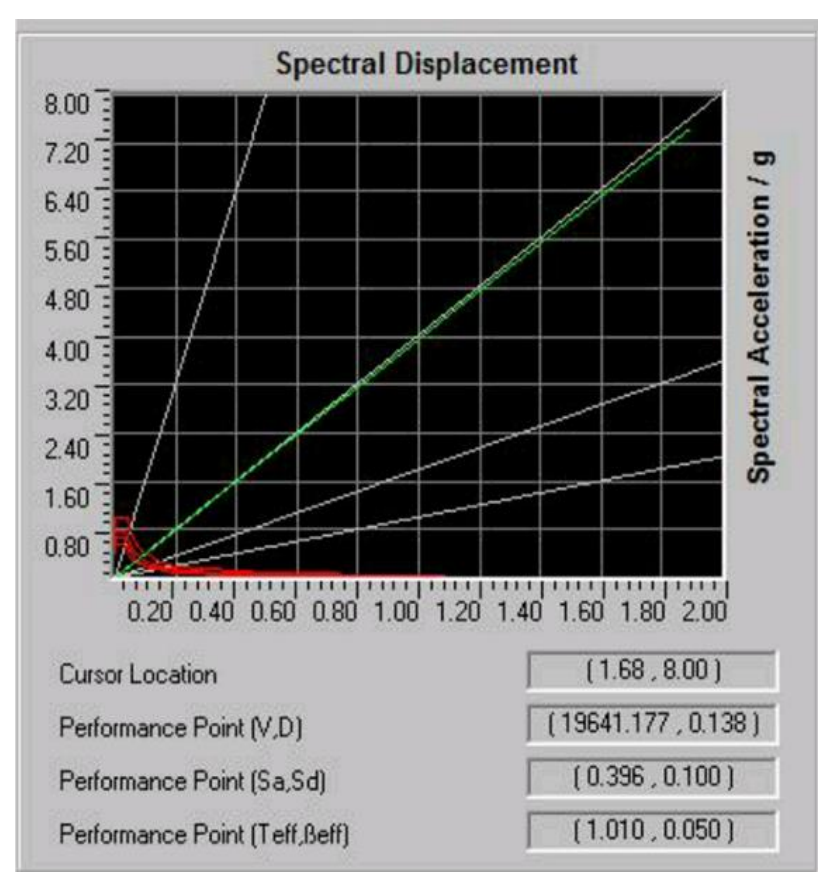

Fig 2.1(b)capacity demand spectrum

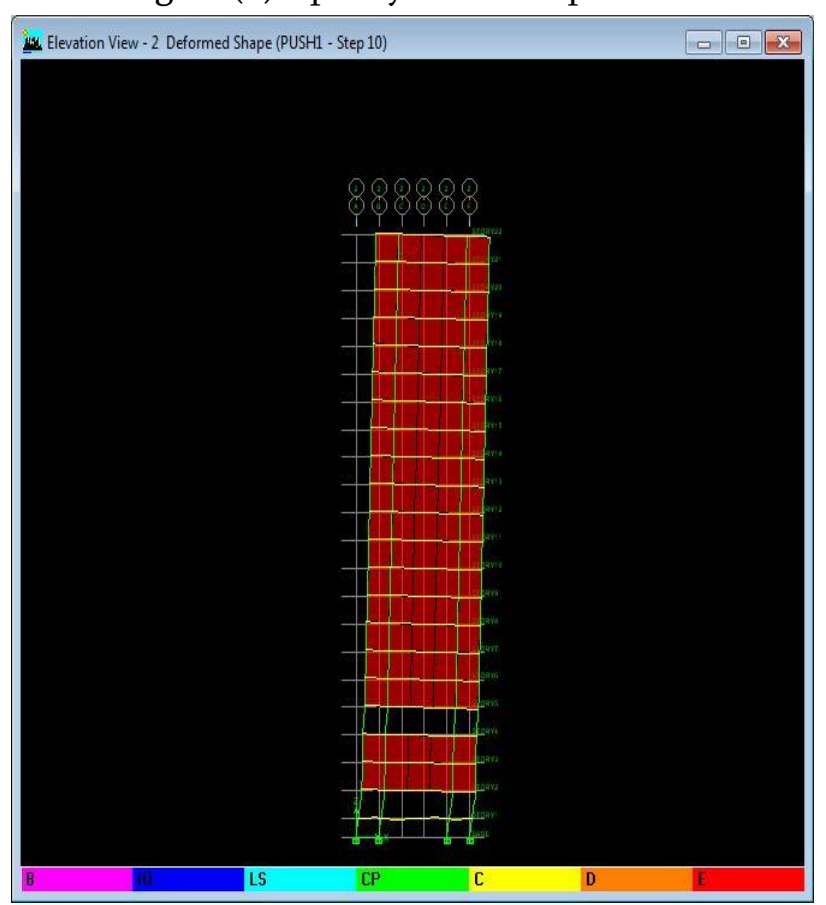

Fig 2.1(c) hinge levels of 22 storey building with soft storey for 22 storey building ground level and third floor
Table 2.2 : Stepwise displacement and base force for soft storey at ground level and third floor

\begin{tabular}{|l|l|l|}
\hline Step & Displacement & Base Force \\
\hline 0 & 0 & 0 \\
\hline 1 & 0.26 & 37029.2188 \\
\hline 2 & 0.52 & 74056.6094 \\
\hline 3 & 0.78 & 111081.5 \\
\hline 4 & 1.04 & 148103.1563 \\
\hline 5 & 1.2999 & 185120.6875 \\
\hline 6 & 1.5599 & 222133.0313 \\
\hline 7 & 1.8198 & 259138.8594 \\
\hline 8 & 2.0798 & 296136.5625 \\
\hline 9 & 2.3397 & 333123.9688 \\
\hline 10 & 2.5996 & 370098.1875 \\
\hline
\end{tabular}

\section{IV.CONCLUSION}

1. Pushover analysis is an elegant tool to visualise the performance level of a building under a given earthquake.

2. Due to the introduction of soft stories in the higher level the intensity of hinge formation becomes lower and lower and at the same time displacement and base shear increases.

3. The pushover curve obtained for the 5-storey building describes that the maximum base force is $6070 \mathrm{KN}$ for a corresponding displacement of $0.086 \mathrm{~m}$

4. The structural effective time period with respect to spectral acceleration for the 5-storey building 0.342 and 0.078 respectively

5. The structural effective time period with respect to spectral acceleration for the 22 storey building 0.396 and 0.050 respectively

6. The pushover curve obtained for the 22-storey building describes that the maximum base force is $19641.17 \mathrm{KN}$ for a corresponding displacement of $0.138 \mathrm{~m}$, however no definite conclusion could be drawn on the formation of hinges in the 22 storied structure, this may be due to introduction of soft stories at different levels. 


\section{REFERENCES}

[1]. H krawinkler and Seneviratna G.D.P.K. "Pros and Cons of a pushover analysis of seismic performance evaluation, Engineering Structures” Vol 20 No4-9 ,pp 452-464, 1998

[2]. Sagupta R and S K Mahajan 'Analysis of multistoried building for construction sequence loading' . International Journal of Modern trends in Engineering and research, July 2015 e-ISSN No 2349-9745

[3]. Rahiman $G$ Khan and $M$ R Vyawahare ' Pushover analysis of tall buildings with soft stories at different levels' International Journal of Engineering Research. Vol 3, Issue 4, pp 176185

[4]. Mohit Gupta ' A case study on Inelastic Seismic analysis of six storey RC building' . International Journal of Engineering Technology, Management and Applid Sciences . Vol 3, Issue 6 ISSN 2349-4476

\section{Cite this article as :}

Dr. M Keshava Murthy, Ashwini L K, "Nonlinear Static Pushover Analysis of Medium Rise and HighRise Building", International Journal of Scientific Research in Science and Technology (IJSRST), Online ISSN : 2395-602X, Print ISSN : 2395-6011, Volume 6 Issue 3, pp. 255-561, May-June 2019. Available at doi : https://doi.org/10.32628/IJSRST1196337 Journal URL : http://ijsrst.com/IJSRST1196337 